\title{
An Assessment of the Effect of Fiscal Decentralisation on Performance of County Governments in Kenya
}

\author{
Elias Peter Mbau, \\ Cyrus Iraya, \\ Mirie Mwangi, \\ James Njihia, \\ University of Nairobi, Department of Finance, Kenya
}

Doi:10.19044/esj.2019.v15n25p109 URL:http://dx.doi.org/10.19044/esj.2019.v15n25p109

\begin{abstract}
The paper focused on the analysis of the influence of fiscal decentralization (FD) on the performance of County governments in Kenya during the transitionary period from a central to a decentralised governance system (2013-2018). The quest for fiscal decentralisation has taken center stage in the past three decades in many parts of the word including Latin America, Asian countries, Africa and throughout the formally planned economies. The study was prompted by conflicting findings from previous empirical studies in both developed and the developing countries. Three indicators of fiscal decentralisation were defined and used in the study. These are the ratio of county governments' funds received from the National Government and local revenue collections. The other is transfer grants, defined as both conditional and unconditional funds received from both national government and development partners. Multiple regression analysis and correlation analysis were used to estimate the parameters of the model. The study was descriptive and used panel data to offer a comprehensive profile of the key variables identified in the conceptual framework. The unit of analysis was the County government with all the 47 counties forming the population of study. The results reveal that $27.43 \%$ of variations in the performance of County Governments are explained by the variables in the model and that equitable share (UB) has the most significant influence. From the several tests applied, the prediction model was confirmed as appropriate.
\end{abstract}

Keywords: Fiscal Decentralisation, National Government, Subnational Governments, Performance 


\section{Introduction}

Fiscal Decentralisation (FD) refers to the transfer of public finance decisions from the central government to Subnational Governments (SNGs) at lower levels (Luiz \& Barenstein, 2001). It is about the question of how governments at lower levels raises their resources to meet their expenditure needs. Salami (2011) posits that once a choice on the governance system has been made, it affects public finance orientation, political governance, and economic wellbeing alongside the achievement of social stability. Kenya promulgated a modern Constitution in the year 2010 and it did away with the colonial constitution which had been found wanting. The latter constitution ushered in a devolved system of governance and drastically transformed the public finance architecture which became effective in 2013.

During the course of the transitionary period spanning from 20132018, the management and sustainability of public finance affairs was clearly thrust to the domain of County Governments (CGs) for the first time in the history of the country with great expectations of making enormous impact on the well-being of residents. Shortly after, these SNGs faced delayed and insufficient transfers from the National government (NG) resulting in underperformance in meeting the expectations of their residents. However, the increasing pressure on public financial requirements is not extraordinary but only became more pronounced owing to a slowdown of overall economic growth, increased unemployment and heightened political activity in the country.

The National Treasury (2017) recognizes the need for fiscal consolidation and fiscal reforms targeting enhanced capacity for revenue collections and public sectors' productivity and efficiency at the SNG level to improve their fiscal positions. To ensure both the devolved and locally collected funds are utilized efficiently, the constitution (2010) compels observance of the principle of openness and transparency in resource allocation. In the initial years of transition, fiscal imbalances quickly emerged as expectations soured and local revenues decreased. This was exacerbated by expenditure reduction on public goods due to institutional and structural malfunctioning, particularly the revenue transmission system commonly known as the Integrated Financial Management Information System (IFMIS). The Controller of Budget (2017) attributes the lackluster performance to lack of capacity to prepare realistic revenue projections as well as detailed revenue forecasts as required by the law (PFMA, 2012). Inefficiency in performance by County governments points to potential for improvement by fully maximizing on all input costs. Hence the objective of this paper: to assess the effect of fiscal decentralisation on performance of County governments in Kenya. Since the devolved system that created the subnational governments was new, barely any literature existed linking fiscal decentralisation and 
performance of county governments in Kenya. Performance analysis provides systematic comparative measurement approaches of outcomes between County Governments making it possible to identify areas that can be improved (Nieswand \& Seifer, 2011). The analysis provides for benchmarking that identify best practices. The purpose of these analyses is also to explain the performance differences and inefficiencies that are due to exogenous factors: determinants that are not fully under the control of DMUs; like population size, land area and equitable share. A clearer understanding of the nature of performance is important for designing policies that improve resource allocation and influences socio-economic growth.

Using a panel data set of 2013-2018 financial years, this study evaluates the relationship between public expenditure management and the expected outcomes of the 47 County governments in Kenya using a wellbeing index measurement model. The study examines and discusses the parameters that may explain the reasons for inefficiency and also assesses the indicators of the outcomes by use of multiple regression analysis.

Two key issues emphasized in multilayered systems to ensure fiscal sustainability and public sector performance are allocation of responsibilities and the management of public spending (OECD, 2003). According to Oates (2005), decision-making responsibility is preferable where people live, work, play and die. This argument is in line with public choice theory as postulated by Balaguer-Coll, Prior, Tortosa-Ausina, (2010). However, according to Zhang and Zhou (1998), it does not hold true that the more decentralised a country's fiscal systems become, the faster its rate of economic development. Indeed Nzau (2014) found that both decentralised capital finance and decentralised recurrent finance contributed negatively to economic growth in Kenya.

The second section provides a history of theoretical and empirical reviews of trends in fiscal decentralisation and also formalizes the conceptual framework that analyses the effect of independent variables on the dependent variable. The third section discusses the relevant data and methodology employed in data collection as well as measurement approaches. The key variables are also identified and described. The fourth section discusses the theoretical and empirical implications of fiscal decentralisation on the performance of subnational governments with respect to the study contextKenya. The fifth section discusses and presents the findings of the study by use of both descriptive statistics and multiple regression analysis that makes use of panel datasets to test the hypothesis. The final section of this paper presents the limitations and conclusions of the study as well as suggestions for further research directions. 


\section{Theoretical foundations and empirical reviews:}

The fiscal federalism theory as postulated by Musgrave $(1959,1989)$ and Oates (1972) is reviewed herein. Oates (1972) Decentralisation Theorem stipulates that some goods and services are uniquely suited for specific regions and not others due to differences in tastes, preferences as well as natural endowments. Decentralisation per se refers to the transfer of expenditure and taxation decision-making powers from central governments to lower levels of government (Luiz \& Barenstein, 2001). While decentralisation can take a variety of forms such as administrative, political, economic and fiscal (Steiner, 2006), it is the latter that this paper focuses on which entails the means and mechanisms of fiscal co-operation in sharing public revenues at all levels of government (Cheema \& Rondinelli, 2007). Fiscal decentralisation is a portion of reform package for improving public sector fiscal systems to enhance efficiency, raise competition among lower level governments in the delivery of public goods leading to accelerated economic development (Bird \& Wallick, 1993).

The use of 'budget data' obtainable from national governments as centrally compiled by International Monetary Fund statistics as well as equitable shares to sub-national governments (SNGs) combines local revenue sources to serve as indicators of fiscal decentralisation (Bodman, 2008). The Kenyan constitution (2010) requires not less than $15 \%$ of all revenues collected nationally to be transferred to SNGs commonly called County governments. More resources are mobilized as equalization funds and local charges and taxation. Drawing on the "Musgravian model" of public sector governmental functions of allocation, stabilization and distribution, Musgrave (1959) anchored the logic of the theory on the principle of subsidiarity. The objective is to focus the role of government to improving the wellbeing of individuals and households at the lowest practicable levels.

Smoke (2001) advances several reasons why the three 'Musgravian' functions are assigned to National government: first, he noted the challenge of SNGs having total independence of control of resources which could threaten the existence of the unitary government. Secondly, he noted local economy's fragile need for externalities/spillover effects and economies of scope. Thirdly, the author underscored the need for deficit financing from creditors/lenders beyond local borders, noting that some types of revenue sources considered most apt for local governments tend to be income-inelastic, hence constraining the ability of CG from pursuing development programs effectively.

Given that previous empirical studies indicate mixed results, the analytical framework of this paper is built on existing models with modifications to suit the study context. After the tumultuous changes occasioned by the promulgation of a modern constitution in Kenya in 2010, 
there was need to empirically analyze the impact of fiscal decentralisation on performance of the devolved units of government commonly known as county governments. The predictor-criterion model employed is as shown below:

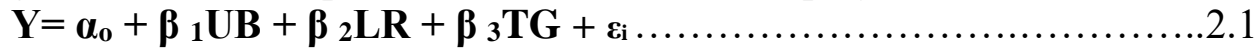

Where $\mathrm{Y}$ is the dependent variable (County Performance), UB is the equitable revenue from the national government, LR is the local revenue collection and TG is the conditional and unconditional transfer grants from national government and other development partners. $\boldsymbol{\alpha}_{\mathbf{o}}$ is the regression constant and $\boldsymbol{\beta}_{\mathbf{1}}-\boldsymbol{\beta}_{\mathbf{3}}$ are the regression coefficients while $\boldsymbol{\varepsilon}$ is the random error term.

The framework of variable operationalization is presented in figure 1 below.

Independent Variable

Figure 1: Conceptual framework

\section{Fiscal Decentralization}

- Equitable Share (UB)

- Local Revenue Collection (LR)

- Conditional/Unconditional Transfers (TG)
Dependent Variable

County Governments Performance

- Wellbeing Ranking ( $\left.\mathrm{W}_{\mathrm{r}}\right)$

(Poverty Levels $\left(\mathrm{P}_{\mathrm{i}}\right)$ )

(Human Development Index (HDI))

Source: Author (2018)

\section{Data and Methodology:}

Using a panel data set of the period 2013-2018 financial years, this article assesses the performance of the 47 County governments in Kenya using an OLS regression model. The study used a data collection form to gather data and information from various institutions such as the National Treasury, Office of the Auditor General, Office of the Controller of Budget, Commission on Revenue Allocation, Kenya National Bureau of Statistics (KNBS), Kenya Institute of Public Policy and Research Analysis among others. The study examines and discusses the parameters that may explain the reasons for performance and also assesses the indicators of the outcomes by use of multiple regression and County wellbeing reports $(2006,2016)$.

There exists a broad category of measurement approaches called basic needs accounts or capability accounts of wellbeing, but one of the most wellknown approach is the UN's Human Development Index (HDI) which identifies the concept of wellbeing as resting upon three factors: income levels and distribution, education levels and health standards. With panel data from all the 47 counties, the researcher used a common class of poverty measures formula as advanced by Ravallion (1998), Sen, Stiglitz, and Fitoussi, (2009) to compute the index of each County. The poverty line is a threshold applied for separating the poor and the non-poor and in this study, it was derived based 
on the cost of basic needs (CBN) approach for a basic basket of goods and services consumed by households using the method adopted by Ravallion (1998). Those above the poverty line are deemed to enjoy a high state of wellbeing as a group or region at a given place and time. The poverty measure, $\mathrm{Pi}$ is defined as:

$$
\mathrm{Pi}=1 / \mathrm{N} \sum_{\mathrm{i}=1}^{\mathrm{N}} \mathrm{I}(\mathrm{Yi}<\mathrm{z}) .
$$

Where:

$\mathrm{N}$ is the population size,

$\mathrm{Yi}$ is the level of individual welfare or real per capita consumption of the $\mathrm{i}^{\text {th }}$ individual,

$z$ is the poverty line,

I is an indicator function that maps the value of one, and zero otherwise.

Wellbeing ratio is defined as:

$\mathrm{Wr}=(1-\mathrm{Pi})$

which should be understood in terms of citizens real opportunities that give all possible combinations of functioning from which they can make choices (Sen, Stiglitz, \& Fitoussi, 2009). The poverty headcount index refers to the number of individuals whose consumption expenditure is below the poverty line as a percentage of total population in the County. It reflects the share of the population who cannot afford to purchase the basic basket of food and nonfood items (KNBS, 2016). This income and expenditure measure is the most commonly used metric in practice for comparison of wellbeing and living standards of individuals and regions. These indicators are sumarised as shown

\begin{tabular}{|c|c|c|c|c|}
\hline Variable & Indicators & $\begin{array}{c}\text { Operational } \\
\text { Definitions }\end{array}$ & $\begin{array}{c}\text { Country level } \\
\text { variables }\end{array}$ & Data Sources \\
\hline $\begin{array}{c}\text { Dependent } \\
\text { Variable }\end{array}$ & $\begin{array}{l}\text { 1. Equita } \\
\text { ble Share }\end{array}$ & $\begin{array}{l}2 . \quad \text { Amount } \\
\text { transferred from } \\
\text { National to } \\
\text { County level }\end{array}$ & $\begin{array}{c}\text { Total National } \\
\text { Budget }\end{array}$ & $\begin{array}{c}\text { Smoke, P (2001) } \\
\text { Wallis and Oates } \\
(1988)\end{array}$ \\
\hline \multirow[t]{2}{*}{$\begin{array}{c}\text { Fiscal } \\
\text { Decentraliz } \\
\text { ation (FD) }\end{array}$} & $\begin{array}{l}3 . \quad \text { Local } \\
\text { revenue } \\
\text { Collection }\end{array}$ & $\begin{array}{l}\text { - Amount of Local } \\
\text { Revenue } \\
\text { Collection }\end{array}$ & $\begin{array}{c}\text { National Tax } \\
\text { Revenue }\end{array}$ & $\begin{array}{l}\text { Luiz\& Barrenstein } \\
\text { (2001) } \\
\text { Tiebout, C (1956) }\end{array}$ \\
\hline & $\begin{array}{l}4 . \quad \text { Conditi } \\
\text { onal/Uncondi } \\
\text { tional Grants }\end{array}$ & $\begin{array}{l}5 . \quad \text { Other } \\
\text { funds from } \\
\text { National } \\
\text { Government, and }\end{array}$ & $\begin{array}{c}\text { External funds } \\
\text { from } \\
\text { donor/developme } \\
\text { nt partners }\end{array}$ & $\begin{array}{c}\text { Constitution of } \\
\text { Kenya (2010) } \\
\text { Oates, W.E } \\
(1972)\end{array}$ \\
\hline
\end{tabular}
in table 1 below.

Table 1: Measurement and operationalization of variables 


\begin{tabular}{|c|c|c|c|c|}
\hline & & $\begin{array}{l}\text { development } \\
\text { partners }\end{array}$ & & \\
\hline $\begin{array}{c}\text { Independe } \\
\text { nt } \\
\text { Variable } \\
\text { Performanc } \\
\text { e of } \\
\text { County } \\
\text { Governme } \\
\text { nts (Wr) }\end{array}$ & $\begin{array}{l}\text { - Per capita } \\
\text { income (PCI) } \\
\text { - Well-being } \\
\text { index } \\
\text { - Human } \\
\text { development } \\
\text { index (HDI) } \\
\text { - Poverty } \\
\text { Levels (PI) }\end{array}$ & $\begin{array}{l}\text { Standards of living, } \\
\text { health, literacy, } \\
\text { employment, } \\
\text { consumption per } \\
\text { capita and general } \\
\text { state of wellbeing }\end{array}$ & $\begin{array}{l}\text { GDP per capita } \\
\text { Rate of GDP } \\
\text { growth } \\
\text { National Poverty } \\
\text { Index }\end{array}$ & $\begin{array}{c}\text { Republic of } \\
\text { Kenya (2012) } \\
\text { KNBS (2016) } \\
\text { National Treasury } \\
\text { (2017) } \\
\text { Sen, Stiglitz, \& } \\
\text { Fitoussi, (2009) } \\
\text { Ravallion (1998) }\end{array}$ \\
\hline
\end{tabular}

Source: Author (2019)

The characterization of well-being postulates a utility function defined over consumption of commodities such that the function produces consumer preferences over alternative consumption bundles (Ravallion, 1998). Hence the poverty line can be interpreted as the point when the consumers expenditure gives the minimum cost to the household or region of attaining a given level of utility at the prevailing market prices. Balassa-Samuelson model (Asea \& Mendoza, 1994) holds that there is a positive association between expenditures, development and performance as measured by HDI. A relative poverty line rises with average expenditure which is proportional to the mean and median income of the population.

In majority of the studies, financial inputs are mainly used rather than physical data. Some authors use one financial aggregate to describe the total inputs while others decompose them into transfers from central government and locally collected finances (Wallis \& Oates, 1988). The advantage of using financial data is that all inputs are comparable and it also implies that DMUs face identical factor prices, and quantities cannot accordingly be wrongly implemented in the estimation (Nieswand \& Seifer, 2011). The total expenditures including equitable share, local revenue collection and conditional grants were used as single and combined inputs employed by County governments to provide the goods and services assigned to them. Using total expenditures as input measure allows the incorporation of all relevant input information on the one hand while also implicitly assuming that input factor prices are the same for all subnational governments for purposes of comparing performance.

On the other hand of outputs, analysis predominantly rely on the tasks that are obligatory to the units' devolved functions. This approach covers the vast majority of costs/expenditures and allows for comparison of performance. To measure these output indicators, literature provides a wide range of means including education literacy, life expectancy, mortality rates, unemployment rates, consumption per capita, well-being levels, inequality index, human 
development index (HDI) as citizens are more concerned about the final outcomes/impact rather than the amount of services delivered (Afonso \& Fernandes, 2006).

Representing the production process of DMUs is complex and difficult to model as wellbeing measurement goes beyond objective reports to include subjective reports and perceptions of the extent of citizens "opportunity set" and their capacity and freedom to choose among these opportunities the life they value (Balaguer-Coll, Prior, Tortosa-Ausina, 2007).

The second stage of analysis used multiple regression model in terms of Ordinary Least Squares (OLS) in order to establish the strength of the independent variable (Fiscal Decentralisation) on the dependent variable (County government performance). The predictor-criterion variables were modelled in the form of the equation defined in section 2 above.

The analysis was undertaken by use of explanatory factors through regression on performance scores obtained earlier in accordance with Ravallion (1998), Sen, Stiglitz, and Fitoussi, (2009) and KNBS (2016) to assess the respective power of each indicator on the criterion. The purpose of these analyses is also to explain the performance differences of each county that are due to exogenous factors such as determinants that are not fully under the control of DMUs like population size, land area and equitable share. A clearer understanding of the nature of performance levels is important for designing policies that improve resource allocation.

\section{Fiscal Decentralisation and Performance of County Governments:}

Fiscal Decentralisation is one of the four commonly used dimensions of decentralisation while the others are political, administrative and economic or market liberalization. Fiscal decentralisation implies existence of multilayered levels of government each with different expenditure functions and responsibilities as well as taxation powers (Luiz \& Bareinstein, 2001). It implies that power on expenditure and revenue raising decisions, previously the preserve of national government is systematically and legally transferred to lower levels of government. The mode of transfer from national government to local government can take different styles and this paper identifies them to include deconcentration, delegation and devolution. Fiscal decentralisation has become an established policy of many developing as well as the developed countries and is actively promoted as a development strategy by organizations like IMF and World Bank (Azfar O. Meagher, P. Lanyi, A. Kakhomen, S \& Diana, R., 2000).

Crucial areas of concern regarding fiscal decentralisation and its impact on economic development are intergovernmental transfer relations, assignment of expenditure responsibilities, territorial jurisdictions, taxation powers and forms of taxes and resource allocation mechanisms (Musgrave, 
1959 and Oates, 1972). These issues form the foundation for protracted discussions, debate, and analyses around the world with different authors and researchers emphasizing on different aspects depending on their context (Baranky \& Lockwood, 2006). Literature provides a wide coverage of empirical studies on the relationships between fiscal decentralisation and economic performance ranging from single, mixed to cross-country studies all-encompassing developing countries, the developed world and OECDs; all of which yield very different results.

While national governments are in a better position to play the role of stabilization especially in light of changes in the international macroeconomic environment (Musgrave, 1989), the fiscal federalism theory also places the principal responsibility for distribution with the central government (Oates, 1972). This duty and its redistributive functions depend invariably on the existing mobility of both resources and individuals. The national government is in a position to redistribute resources from wealthier to poorer jurisdiction through apt taxation measures (Hyman, 2005).

Though there have been challenges to the conventional recommendation that distribution be centralized, local governments tend to have access to revenue sources that are not easily levied in a manner that is progressive with respect to income (Abachi \& Salamu, 2012).

The allocation function considers preference-matching and welfare gains of residents in the absence of market and competitive pricing mechanisms, for public service goods (Taylor, 1993). Community-wide demands through stakeholders and public participation, articulated through collective-decision making process is taken to reflect value for money for identified priorities (Tiebout, 1956). Hence fiscal decentralisation is desirable not just because of preference differentiation but also because expenditure decisions are tied more to taxation measures within local jurisdictions. Furthermore, where there are larger numbers of subnational governments, there's likely to be greater competition and greater experimentation and innovation in the provision of goods leading to enhanced performance and productivity (Adan, C., Matsushima, Y., Hernandez-Sierra, R., MarcoFerreres, R., Fernandez-Moreno, M.A., Gonzalez-Vioque, E., Calleja, M., Aragon, J.J., Kaguni, L.S., Garesse, R. 2008).

These devolved governments lead to enhanced performance in the management of economic resources as the decentralised systems are more transparent in defining the role of various public agents and place a greater premium on accountability for results (Huther \& Shah, 1998). In this sense, provision of resources at the decentralised level in contrast to the monopolistic position of central governments that presumes 'one-size-fits-all' leads to faster redress of the challenges of poverty, inequality, illiteracy, poor health, insecurity and lack of skills that prevents individuals from realizing their full 
potential (Tiebout, 1956). However, there are certain exceptions to this general rule of decentralisation when it comes to capital intensive goods such as transportation, electricity connectivity which are more amenable to economies of scope in production. In such cases, resource allocation is more efficient when service provision area is drawn such that externalities are internalized (Leibenstein, 1966).

Since gaining independence in 1963, Kenya has grappled with various types of decentralisation which have oscillated from delegation to the more comprehensive constitutional form of devolution in 2010. Mwenda (2010) opines that the current constitution brought in dramatic changes in how the country is governed with its primary objective being to promote democratic and accountable exercise of power, foster national unity, confer power of selfgovernance and engagement to local communities and promote social and economic development. The key drivers of clamor for devolution in Kenya were corruption, wastage and unequal distribution of public resources which was a clear recipe for political instability (Ndii, 2010).

The devolution process that took effect in 2013 began transferring at least $15 \%$ of National Governments revenue to the 47 devolved government units for use in their various development activities (CoK, 2010). The amount is shared among all the Counties on a set criterion that regards population size, poverty levels as well as the physical landmass of the Counties. Similarly, the county governments mobilize their own revenues from local sources to supplement the transfers from the national government. The national government also continues with intergovernmental transfers of grants and other conditional funds to undertake nationally identified projects and programs within the Counties (Kirira, 2011).

Fiscal decentralisation is expected to deliver equity in resource sharing and has a known positive influence on governance and government quality (Huther and Shah, 1998). To ensure both devolved and locally collected funds are utilized efficiently to achieve maximum impact in the well-being of residents, the Kenyan Constitution (2010) compels County governments to observe the principle of openness and transparency and additionally requires them to absorb as much of the available funds as practically possible.

\section{Analysis and Presentation of Results:}

The following section is a discussion report for the articles' main objective- which was to assess how fiscal decentralisation affected the performance of County governments in Kenya between 2013 and 2018. The paper hypothesized that the effect of fiscal decentralisation on performance of County governments in Kenya was not significant. 


\section{Descriptive statistics}

A preliminary analysis of descriptive statistics was done to enable presentation of data in a simpler manner for ease of interpretation. The analys is was to establish the measures of central tendency, the standard deviation as well as normality. The test for normality was done by use of Shapiro-Wilks which indicated normality of distribution of the variables. The results are shown in table 2 below:

Table 2: Summary of descriptive statistics

\begin{tabular}{|l|c|c|c|c|}
\hline Variable & UB & LR & TG & Wr \\
\hline Mean & $\mathbf{5 . 5 2 7}$ & $\mathbf{0 . 6 8 2}$ & $\mathbf{8 . 8 7 9}$ & $\mathbf{0 . 5 0 9}$ \\
Maximum & 14.045 & 11.71 & 51.63 & 0.782 \\
Minimum & 2.052 & 0.027 & 1.598 & 0.125 \\
Std deviation & 2.073 & 0.161 & 7.857 & 0.164 \\
Skewness & 1.749 & 5.553 & 2.262 & -0.636 \\
Kutorsis & 3.399 & 32.799 & 5.733 & -0.279 \\
Shapiro - & 0.904 & 0.351 & 0.917 & 0.959 \\
Wilks & $\mathbf{2 3 5}$ & $\mathbf{2 3 5}$ & $\mathbf{2 3 5}$ & $\mathbf{2 3 5}$ \\
\hline Observation & \multicolumn{3}{|c|}{ Source: Author (2019) }
\end{tabular}

\section{Diagnostic Tests}

Prior to proceeding with the analysis, the data collected was subjected to rigorous diagnostic tests in order to verify and validate its suitability.

\section{Multicollinearity}

As highlighted by Piana, Cardoso, Dias, Gomes, Agostinho and Miranda (2017), multicollinearity tests are crucial especially in order to check whether the predictors in a regression model are themselves correlated. Accordingly, the test was conducted on the three variables under fiscal decentralization namely equitable allocation from the national government, local revenue collections by the County government as well as conditional and unconditional grants given to the counties. This was done by use of variance inflation factors (VIF) which according to DeForest, Brix, Tear and Adams (2018) is a measure of the extent to which the residues in a multivariate linear regression is inflated by its correlation with other concepts in the model. It's a phenomenon where a predictor variable in a multiple regression model can also be linearly predicted and inferred from the others.

Table 3: Results of multicollinearity tests

\begin{tabular}{ccc}
\hline Variable & VIF & 1/VIF \\
\hline Equitable Share (UB) & 6.56 & 0.152360 \\
Local Revenue (LR) & 1.68 & 0.593864 \\
Transfer Grants (TG) & 1.20 & 0.834365 \\
\hline
\end{tabular}

Source: Author (2018)

As indicated in table 3 above, since all the values of variance inflation factors were below 10, it can be confirmed that indeed they are not significant 
in the correlations among the independent variables which were used in the model namely equitable share from the national government, conditional and unconditional grants as well as local revenue collected by the County governments (Deforest Brix, Tear and Adams, 2018).

\section{Unit Root Tests}

A unit root is a feature of random probability distribution process involving time series models that can occasion challenges in statistical inference. It is a trend in a time series that displays a systematic pattern that is unpredictable. Existence of a unit root can cause serious issues in statistical analysis like spurious regression or errant behavior of results (Long, Sun, Cheng \& Zhang, 2017). A unit root is one of the causes of non-stationarity. In this study, a test for existence of unit root was conducted by use of Augmented Dickey Fuller (ADF) technique which tests the null hypothesis that a unit root exists in a time series data set.

Table 4: Unit Root Test

\begin{tabular}{cccl}
\hline Variable & ADF Test & P-Value (95 \% confidence interval) & Remarks \\
\hline WI & -0.208 & 0.05 & Stationary \\
UB & -0.531 & 0.02 & Stationary \\
LR & -0.532 & 0.00 & Stationary \\
TG & -5.941 & 0.04 & Stationary \\
\hline
\end{tabular}

Source: Author 2018

The findings summarized in the table 4 above reveal that all the three variables for the 235 observations yielded p-values that were less than the 0.05 level of significance implying that they all met the required condition of stationarity.

\section{Heteroscedasticity Tests}

This is yet another critical test in most of econometric and statistical analysis. Adamec (2017) highlights that the test is used to check for the presence of various patterns of non-constant variances in the linear model. The presence of heteroscedasticity in the application of regression analysis is of great of concern as it can invalidate or bias the significance of statistical tests. The research used Breusch-Pagan / Cook-Weisberg test. For the model to hold the variance of residues should be constant otherwise they would be referred to as being heteroscedastic. 
Table 5: Results of tests for heteroscedasticity

Breusch-Pagan / Cook-Weisberg test for heteroskedasticity

Ho: The residuals of the regression are homoscedastic.

Variables: fitted values for wellbeing 2016

$$
\operatorname{chi} 2(1)=0.67
$$

Prob $>$ chi $2=0.4119$

Source: Author (2018)

Table 5 above provides results for test of heteroscedasticity which was carried out on the basis of the null hypothesis that indeed the residuals of the regression are constant in the given set of data. As clearly summarized in the table above, the value of the test statistic which is the chi-square equals to 0.67 , which furthermore has a p-value of 0.4119 which is above 0.05 . This leads to failure to reject the null hypotheses $\left(\mathrm{H}_{0}\right)$, in other words there is constant variance in the datasets or the data is homoscedastic.

\section{Autocorrelation Tests}

In order to check for autocorrelation, the study employed the Durbin Watson test statistic which is used to test for first order serial correlation. This is a measure of correlation between the errors of a series and others from the same series and can be positive or negative (DeForest Brix, Tear and Adams, 2018). The study hypothesized a null hypothesis that there does not exist a first order autocorrelation from the regression analysis. The test proceeded to examine if serial residuals are autocorrelated at a $P$-value of 0.05 .

Table 6 below provides the results for autocorrelation tests on the residuals.

Table 6: Autocorrelation tests on residuals

$$
\text { Durbin-Watson d-statistic }(4,235)=1.9032
$$

Source: Author (2018)

Since the calculated value of the test statistic for this study was 1.9 , it can be said that indeed there was no statistically significant serial correlation between the residuals of the regression model based on the equitable share from the national government, conditional and unconditional grants as well as local revenue collected by the national government as the independent variables. Hence independence of the residuals is maintained.

\section{Cointegration tests}

In empirical statistics, it is common and important to fit vector autoregressive (VAR) models as a preliminary step in order to estimate Impulse responses. The purpose is to make sure that the right number of lags are selected for the fitted model in order to come up with an optimal lag length among multiple time series data. Each variable is considered a linear function 
of past lags of the other variables. The analysis was undertaken by making a null hypothesis that there is no cointegration amongst the variables. The study used the Johansen methodology which makes use of the Maximum Likelihood (ML) estimator of the parameters. The study results are in table 7 below.

Table 7: Cointegration results

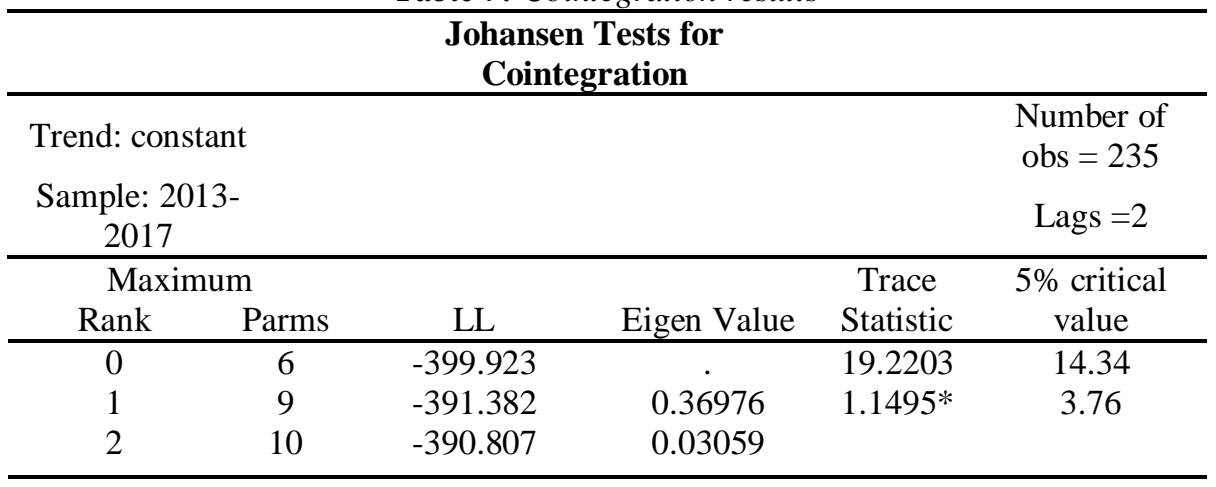

Source: Author (2019)

After determining that there was indeed a long run relationship between fiscal decentralisation and performance of county governments, a vector error correction (VEC) was conducted and the results are summarised in table 8 below.

Table 8: Vector Error Correction Model

\begin{tabular}{|c|c|c|c|c|c|c|}
\hline $\begin{array}{c}\text { D_Wellbeing } \\
\text { Index }\end{array}$ & Coef. & Std. Err. & $\mathbf{z}$ & $\mathbf{P}>\mathbf{z}$ & $\begin{array}{l}{[95 \%} \\
\text { Conf. }\end{array}$ & Interval \\
\hline L1. & 1 & 0.056163 & 0.58 & 0.561 & $\begin{array}{c}- \\
0.0774558\end{array}$ & 0.142699 \\
\hline $\begin{array}{l}\text { _cons } \\
\text { D_UB }\end{array}$ & 0.598432 & 38.98808 & 0.02 & 0.988 & -75.8168 & 77.01367 \\
\hline $\begin{array}{l}\text { L1. } \\
\text { cons }\end{array}$ & $\begin{array}{l}0.009822 \\
-1.14739\end{array}$ & $\begin{array}{l}0.003804 \\
2.640344\end{array}$ & $\begin{array}{c}2.58 \\
-0.43\end{array}$ & $\begin{array}{c}0.01 \\
0.664\end{array}$ & $\begin{array}{l}0.0023678 \\
-6.322367\end{array}$ & $\begin{array}{c}0.017277 \\
4.02759\end{array}$ \\
\hline $\begin{array}{c}\text { D_LR } \\
\text { L1. } \\
\text { cons }\end{array}$ & $\begin{array}{c}0.00662 \\
-1.39429\end{array}$ & $\begin{array}{l}0.001461 \\
1.014375\end{array}$ & $\begin{array}{r}4.53 \\
-1.37\end{array}$ & $\begin{array}{c}0 \\
0.169\end{array}$ & $\begin{array}{l}0.0037564 \\
-3.382425\end{array}$ & $\begin{array}{l}0.009484 \\
0.593852\end{array}$ \\
\hline $\begin{array}{c}\text { D_TG } \\
\text { L1. } \\
\text { cons }\end{array}$ & $\begin{array}{l}0.000411 \\
2.379055 \\
\end{array}$ & $\begin{array}{l}0.001347 \\
0.934838 \\
\end{array}$ & $\begin{array}{l}0.31 \\
2.54 \\
\end{array}$ & $\begin{array}{c}0.76 \\
0.011 \\
\end{array}$ & $\begin{array}{l}-0.002228 \\
0.5468055 \\
\end{array}$ & $\begin{array}{l}0.003051 \\
4.211304 \\
\end{array}$ \\
\hline
\end{tabular}

The study findings indicate that the three components of fiscal decentralisation had a positive relationship with their first lags and that the relationship of lags between equitable share and local revenue collections had a statistically significant relationship with their first lags.

The variables of the regression model were then tested and coefficients of the equation computed as shown below: 
Table 9: Model Summary and ANOVA Table

\begin{tabular}{ccccc}
\hline Source & SS & Df & MS & $\begin{array}{c}\text { Number of obs }=\mathbf{2 3 5} \\
\mathbf{F}(\mathbf{3 , 2 3 1})=\mathbf{3 0 . 4 8}\end{array}$ \\
\hline Model & 1.79443444 & 3 & 0.598144814 & Prob $>$ F $=0.000$ \\
Residual & 4.53327965 & 231 & 0.019624587 & $\begin{array}{c}\text { R-squared }=0.2836 \\
\text { Adj R-squared }= \\
\end{array}$ \\
& & & & 0.2743 \\
Total & 6.32771409 & 234 & 0.027041513 & Root MSE $=0.14009$ \\
\hline
\end{tabular}

Source: Author (2018)

Table 10: Coefficients for the Regression Model

\begin{tabular}{ccccccc}
\hline $\begin{array}{c}\text { Wellbeing } \\
\text { Index }\end{array}$ & Coef. & Std. Err. & T & P>|t| & [95\% Conf. Interval] \\
\hline UB & 38.16894 & 6.048397 & 6.31 & 0.000 & 26.25187 & 50.08602 \\
LR & 0.0697662 & 0.007325 & 9.53 & 0.000 & 0.0553348 & 0.0841975 \\
TG & 0.0001425 & 0.001275 & 0.11 & 0.911 & -0.0023695 & 0.0026545 \\
cons & 0.6717895 & 0.030021 & 22.38 & 0.000 & 0.612639 & 0.73094 \\
\hline \multicolumn{6}{c}{ Source: Author (2018) }
\end{tabular}

It was observed from table 9 that the explained variation of the dependent variable equaled $27.43 \%$ which is interpreted to have been caused by variations in the independent variables. The balance $72.57 \%$ is assumed to be due to other unexplained factors. Taking the significance level of $95 \%$, the value of the F-ratio $(\mathrm{F}=30.48)$ had a $\mathrm{P}$-value $=.000$ which was less than the level of significance (0.05). This means that the ratio of variations caused by the model and the residual is statistically significant. This therefore implies that regression model adopted is suitable for the prediction of the various relationships.

Table 10 above which depicts the coefficients for the regression model shows results of testing the effect of each indicator of the independent variable on performance. The specific indicators of the variables are as defined in equation 2.1. Tests for linearity of the respective indicators were conducted in order to confirm that the data was derived from a population that relates with the variables of interest proportionately as recommended by Damon (2017). It is clear that the highest positive regression coefficient was equitable revenue (UB) from the National government, followed by Local Revenue (LR) while conditional/unconditional grants from various sources were not a significant predictor. In this model, output is produced from the inputs of equitable share, local revenues and conditional transfers. Table 10 shows that all the $\mathrm{P}$-values were less than 0.05 at the $95 \%$ significance level except that of conditional grants. This led to the rejection of the null hypothesis and acceptance of the alternate hypotheses. On this score of achievements of the devolved system of governance, Kirira (2011) states that devolution has presented a major transformation of the country and undoubtedly reversed the system of 
centralized control and authority established by the colonial powers. Additionally, a report by Mo Ibrahim Foundation, on Index of African Governance (2018) observed that Kenya recorded progress in governance alongside long term performance. The report noted that the country did remarkably well in sustainable economic opportunity score which measures the extent to which governments enable their citizens to pursue economic goals and give them opportunity to prosper. This result is supported by Martinez-Vazquez, Jorge \& McNab (2003), who held that though the relationship between fiscal decentralisation and economic growth remains mixed and controversial, decentralisation has positive impacts on efficient allocation of resources, democratic governance and enhanced accountability.

\section{Limitations}

This paper acknowledges that one of the key limitations of being able to establish the effects of fiscal decentralisation on performance of County governments is the presence of other variables such as allocative efficiency, governance and politics. In addition, other exogenous factors such as population size, size of respective regions and their attendant poverty/wellbeing status also had a certain level of effect on the outcomes of performance of County governments. The so-called attribution challenge is further exacerbated by the inability to relate outcomes directly due to existence of a huge number of private and public players within the territorial context of County governments activities.

\section{Conclusions}

The specific objective of this paper was to assess the effect of fiscal decentralisation on the performance of subnational governments in Kenya. From the literature, it is noted that policy reforms and their impact on government performance can be broken down for analytical purposes into three broad perspectives. Firstly, is a focus on the changes taking place in the level of economic activities in terms of wages and prices of goods and services which increase incomes of small-scale farmers, laborers and traders as well as workers in the informal sector. Secondly is human development or improvements in the quality of life as reflected in their access to health, education, sanitation and higher life expectancy. The third perspective is spatial or inter-regional inequality that reflects the extent of redistributive justice or growth between deprived and economically wealthier areas; in terms of social inequality through redistribution of incomes.

Fiscal Decentralisation has presented a major transformation package

of the country and undoubtedly reversed the system of centralized control and authority established by the colonial powers to a more inclusive system, leaving the future looking bright. From the three indicators of fiscal 
decentralisation, used in the study, the findings indicate that County governments (CGs) heavily depend on the National government (NG) for revenues to finance their expenditure functions. Their own sources of revenue is negligible compared to their receipts from the national government.

With the coefficient of determination (r2) being observed as $27.43 \%$, it can therefore be concluded that higher amounts of transfers from the National governments to the subnational governments will have a positive and significant influence on the performance of county governments in Kenya. The Commission on Revenue Allocation (2014) held that by allocating a constant amount of funds to various counties and giving them increased flexibility, the units are able to institute timely preparation of budgets and promote fiscal probity and responsibility, leading to enhanced performance.

This conclusion supports the findings by Bodman (2008) who in an analysis of fiscal decentralisation and economic development in Spain found that decentralisation has a positive relationship for communities with a high degree of fiscal autonomy.

It is expected that the inter-county differences in tax policies, expenditure priorities, accountability and human capacity at the local level are key determinants of cross county variations in performance of County governments. This is because needs are not homogenous over counties or even within regions of an individual county. It's imperative for subnational governments to recognize the different needs of citizens and pay special attention to the poor and disadvantaged groups. This process is actually done through direct assessment of citizens' needs followed by public participation to prioritize and engender ownership under hard budget constraints. Population size within counties also affects greatly the per capita expenditures as higher growth of population lowers per capita incomes because the available resources must be spread more thinly over the entire population (Mankiw, Romer, \& Weil, 1992). The paper recommends legal amendments to enforce a hard budget constraint and streamlining of local capacity taxation mechanisms to ensure transparency and accountability to local residents in order to enhance local revenue collection and improve performance. County governments must be made to understand that they must work harder on raising local revenues and become more prudent in their budgeting and expenditure plans. They must also acknowledge the fact it does not help for the National government to continue transferring funds to them which comes from taxing others who also deserve goods and services by the taxes they pay.

This is in view of the fact that despite the huge investments made by National government and devolution of huge resources to county governments, absorption and performance have been slowed down due to its bureaucratic nature, lack of adequate capacity, corruption and inadequate political will leading to systematic resource mis-allocation. The study 
objective which was to assess the relationship between fiscal decentralisation and performance of County governments in Kenya is therefore achieved.

\section{Future research directions}

Future research can be focused on establishing the post transition relationships amongst the key variables. Other studies could focus on assessing the relationship of fiscal decentralisation for sampled number of county governments and not the whole population. Furthermore, scholars can conduct case studies of individual county governments that can examine the relationships between selected variables such as health, education, infrastructure among others. This may be necessary given that counties are highly heterogeneous and straddle very diverse climatic and physical conditions; and their geographical and population sizes also differ markedly.

\section{References:}

1. Abachi, P \& Salamu I. (2012). An analysis of the effect of fiscal decentralization on economic growth in Nigeria. International Journal of Humanities \& Social Science, 2 No.8.

2. Adan, C., Matsushima, Y., Hernandez-Sierra, R., Marco-Ferreres, R., Fernandez-Moreno, M.A., Gonzalez-Vioque, E., Calleja, M., Aragon, J.J., Kaguni, L.S., Garesse, R. (2008). Mitochondrial transcription factor B2 is essential for metabolic function in Drosophila melanogaster development. J. Biol. Chem. 283(18): 12333--12342.

3. Afonso, A \& Fernandes, S (2006). Measuring local government spending efficiency: evidence for the Lisbon Region. Regional Studies, 40: 39-53.

4. Ankamah (2012). Local Revenue administration and development finance in Ghana: Edupedia Publications (P) Ltd.

5. Asea, P. K., \& Mendoza, E. G. (1994). The Balassa-Samuelson Model: A General-Equilibrium Appraisal*. 2(3), 244-267.

6. Azfar, O. Meagher, P. Lanyi, A. Kakhomen, S \& Diana, R. (2000). Conditions for effective decentralized governance: A synthesis of research findings. IRIS Centre WP, University of Maryland.

7. Balaguer-Coll, M. \& Prior, D. \& Tortosa-Ausina, E. (2007). On the Determinants of Local Government Performance: A Two-Stage Nonparametric Approach. European Economic Review. 51. 425-451. 10.1016/j.euroecorev.2006.01.007.

8. Balaguer-Coll M. \& Prior, D. \& Tortosa-Ausina, E. (2010). Decentralization and efficiency European Economic Review in Spanish local government. The annals of regional science. 45 (3): 571601. Springer (2009). 
9. Barankay, I. \& Lockwood, B (2006) Decentralization and the productive efficiency of government: Evidence from Swiss Cantons. CEPR Discussion Papers. 5639.

10. Bird, \& Wallick. (1993). Contribution of fiscal decentralization to Economic Growth: Evidence from Pakistan.

11. Bodman, P. (2008). Fiscal federalism and economic growth in the OECD, Paper presented at the "Future of Federalism" Conference, Brisbane.

12. Cheema \& Rondinelli (2007). Decentralizing Governance: Emerging concepts and practices (eds). The journal of Federalism, 38 (4) 741 743. Brookings Institution Press, Washington DC.

13. Commission on Revenue Allocation (2014), Kenya.

14. Deforest, D., Brix. K., Tear, L., \& Adams, W. (2018). Multiple linear regression models for predicting chronic aluminium toxicity for fresh water aquatic orgasims and developing water quality guidelines. Environmental toxicity \& chemistry, 37(1), 80-90.

15. GoK, Budget Implementation Review Reports. Office of the Controller of Budget. (2013 - 2018), Nairobi, Kenya.

16. Huther, J. \& Shah, N. (1998). A Simple Measure of Good Governance to the Debate on Fiscal Decentralization. ECLAC Seminar, World Bank, Washington, DC.

17. Hyman, D. (2005). Public Finance: A Contemporary Application of Theory to Policy, $8^{\text {th }}$ edition, Thomson/South Western, Ohio.

18. Ibrahim Index of African Governance. (2018).

19. Kenya National Bureau of Statistics, KNBS. (2016). Spatial Dimensions of Wellbeing in Kenya, Nairobi.

20. Kirira, N. (2011). Public finance under Kenya's new constitution; Society for International Development, Nairobi. The Regal Press.

21. Leibenstein, H. (1966). Allocative efficiency vs. "X-efficiency", The American Economic Review, 56, .392-415.

22. Luiz, D. \& Barenstein, M. (2001). Fiscal decentralization and governance: A cross-country analysis. IMF Working Paper No. 01/71.

23. Mankiw, G., Romer, D., \& Weil, D. N. (1992). A CONTRIBUTION TO THE EMPIRICS OF. (May).

24. Martinez-Vazquez, Jorge \& McNab (2003). Fiscal Decentralization and Economic Growth, World Development Report, 31, (9), 15971616.

25. Musgrave R. A \& Musgrave P. B (1989). Public Finance in Theory and Practice, $5^{\text {th }}$ Edition, McGraw Hill.

26. Musgrave, R.A. (1959). The theory of public finance. New York: McGraw-Hill 
27. Mwenda, A. K. (2010). Economic and administrative implications of devolution framework established by the constitution of Kenya; Institute of Economic Affairs, Nairobi.

28. National Treasury (2017). Enhancement of County governments Own Source Revenue Kenya.

29. Ndii, D. (2010). Decentralization in Kenya. Background note.

30. Nieswand, M. \& Seifer, S. (2011): Some determinants of intermediate local governments spending efficiency: The case of French departments. Discussion papers, No. 1130. Berlin.

31. Nzau, M. (2014). The effects of devolved funds on economic growth in Kenya: Empirical investigation (1993 - 2012), Unpublished M.A Economics Thesis, University of Nairobi.

32. Oates, W.E. (1972). Fiscal federalism, Harcourt, Brace, Jovanovich, New York.

33. Oates, W.E. (2005). Toward a second generation theory of fiscal federalism, International Tax and Public Finance, 12, 349 - 373, Springer Science.

34. OECD (2003). Key competencies for a successful life and wellfunctioning society. Hogrefe \& Huber Publisher.

35. Oswald, A. (1980). Happiness and economic performance. The Economic Journal, 107, 1815-1831

36. Ravallion, M. (1998). Poverty Comparisons: Fundamentals of Pure and Applied Economics, Chur, Switzerland. Hardwood Academic Press.

37. Republic of Kenya, Nairobi. Public Finance Management Act (2012) Government printer

38. Republic of Kenya. (2010). Constitution of Kenya (2010). Government Printer, Nairobi.

39. Salami, A. (2011). Taxation, revenue allocation and fiscal federalism in Nigeria: issues, challenges and policy options, Economic Annals, LVI, No. 189

40. Sen, A., Stiglitz, E., \& Fitoussi, J. (2009). Report by the commission on the measurement of economic performance and social progress. Paris, France.

41. Smoke, P. (2001). Fiscal Decentralization. A Review of Current Concepts and Practice. UNRISD, Paper No. 2, ISSN 1020 - 8186.

42. Steiner, S. (2006). Decentralization in Uganda: Exploring the constraints for poverty reduction, GIGA-WP-31/2006, German institute of Global and Area Studies.

43. Taylor, L. (1993). Allocative inefficiency and local government: evidence rejecting the Tiebout hypothesis. Federal Reserve Bank of Dallas Research Paper No. 9319. 
44. Tiebout, C. (1956). 'A pure theory of local expenditures.' Journal of political Economy 64, 416 - 424, University of Chicago Press.

45. Wallis, J. J. \& Oates, W. (1988). Decentralization in the public sector: An empirical study of state and local government, 5 -32, University of Chicago Press

46. Zhang \& Zou (1998). Fiscal decentralization, public spending and economic growth in China. Journal of Public Economics. 67, 221-240. 